\title{
PESANTREN SEBAGAI PUSAT SERTIFIKASI DAN EDUKASI SDI PARIWISATA SYARIAH DALAM PENGUATAN INDUSTRI HALAL DI INDONESIA
}

\author{
Moh Suyudi, Ahmad Muhlis, Mansur \\ STAI Miftahul Ulum Pamekasan \\ aqliyyahdzakiyyatul@gmail.com
}

DOI: https://doi.org/10.21107/dinar.v6i2.6472

\begin{abstract}
Abstrak
Sertifikasi profesi bagi sumber daya insani di Indonesia adalah hal yang sangat penting. Apalagi jika melihat growth industry kenangan maupun bisnis syariah yang cukup pesat, maka dirasa sangat perlu adanya upaya penanaman ilmu ekonomi ilabiyah tersebut pada generasi yang lebih muda yakni pondok pesantren yang menjadi pusat edukasi dalam pembentukan kreatifitas dan keablian.

Pendekatan yang digunakan dalam penulisan karya tulis ini adalab deskripsi kualitatif berdasarkan kajian kepustakaan. Sumber sekunder didapatkan dari buku-buku yang relevan dengan topik penulisan, karya tulis ilmiah, artikel, serta jurnal dari internet.

Penelitianini menemukan bahwa industri halal akan menjadikan sertifikasi sebagai bekal menghadapi segala kemungkinan yang akan terjadi pada persaingan kompetensi di pasar kerja. Adapun konsep pengintegrasian sertifikasi syariah dengan pondok pesantren secara sistematis merupakan suatu strategi yang cukup jitu untuk menghasilkan generasi-generasi muda muslim calon praktisi maupun akademisi yang mafhum akan ekonomi syariah. Kompetensi yang didukung dengan sertifikasi ini, akan menghasilkan SDI-SDI berkompeten yang akan mampu menggerakkan pariwisata syariah dengan kualitas dan daya saing yang tinggi.
\end{abstract}

Kata kunci: Edukasi, Pariwisata Syariah, Industri Halal, Sumber Daya Insani, Sertifikasi Syariah 


\section{Pendahuluan}

Indonesia adalah negara kelima dengan populasi terbesar di dunia sekaligus negara pertama dengan populasi muslim terbesar di dunia (Invesments, 2016). Sektor pariwisata merupakan sektor yang menjanjikan bagi Indonesia. Negara dengan ribuan pulau, banyak budaya, dan beragam tempat menarik menjadi keunggulan dan daya tarik tersendiri bagi para pelancong dari dalam maupun luar negeri. Dengan pengelolaan yang baik dari masyarakat maupun dukungan pemerintah, sektor pariwisata akan berkontribusi makin besar pada pertumbuhan ekonomi Indonesia. Perkembangan sektor pariwisata juga berdampak linier terhadap daya saing Indonesia dengan negara lain dalam MEA (Suroso, 2015).

Menteri Pariwisata dan Ekonomi Kreatif, Mari Elka Pangestu menyatakan bahwa Masyarakat Ekonomi ASEAN (MEA) yang akan berlaku efektif di akhir tahun 2015 berpotensi untuk mendorong pertumbuhan jumlah wisatawan ke Indonesia yang kini masih sekitar 9\% pertahun menjadi di atas 10\%. Sepanjang periode 2005-2012, pariwisata kawasan Indonesia mampu tumbuh rata-rata 8,3\% pertahun, jauh di atas rata-rata pertumbuhan global yang hanya 3,6\%. Bahkan pada 2013, arus kunjungan wisatawan ke negara-negara ASEAN sudah mencapai 92,7 juta atau meningkat 12\% dibandingkan tahun sebelumnya, sementara pertumbuhan global hanya $5 \%$.

Pemerintah menunjukkan keseriusannya dalam pengembangan pariwisata Indonesia dengan mengeluarkan PP Nomor 52 Tahun 2012 tentang Sertifikasi Kompetensi dan Sertifikasi Usaha Bidang Pariwisata. Adanya 2 kategori sertifikasi tersebut tentu saja secara signifikan akan meningkatkan kualitas pariwisata di Indonesia. Sektor pariwisata Indonesia dinilai menjadi sektor yang paling siap dalam MEA serta era industry Halal dari sisi SDM. Wakil ketua Badan Nasional Sertifikasi Profesi (BNSP), yang dikutip karena memiliki lembaga sertifikasi yang mumpuni. Meskipun sektor pariwisata bukan termasuk 14 sektor ekonomi kreatif, namun kemajuan pariwisata berdampak pada pertumbuhan ekonomi kreatif (Wangke, 2015).

Pembangunan kepariwisataan perlu didukung oleh SDM yang berkompeten dalam rangka memberikan pelayanan prima bagi wisatawan. Undang-Undang Nomor 10 Tahun 2009 tentang Kepariwisataan mengamanatkan bahwa tenaga kerja di bidang kepariwisataan wajib memiliki standar kompetensi melalui sertifikasi. Sertifikasi sangat diperlukan dalam menghadapi persaingan tenaga kerja tingkat nasional maupun internasional apalagi dengan kaitannya menghadapi persaingan global. Tidak terkecuali untuk tren saat ini, yaitu pariwisata syariah yang telah di-booming-kan oleh beberapa negara, termasuk Indonesia. Pariwisata syariah merupakan konsep yang mengintegrasikan nilainilai syariah ke dalam kegiatan pariwisata dengan menyediakan fasilitas dan pelayanan yang sesuai dengan ketentuan syariah (Muhajirin, 2018).

Hal ini tentu sangat riskan mengingat perkembangan ilmu pengetahuan dan teknologi sudah semakin maju, terutama menyangkut relevansi dengan kebutuhan tenaga kerja yang sudah semakin dinamis, yang tentunya menuntut sumber daya manusia yang 
profesional secara teknis dan filosofis agar Indonesia dapat menjadi bangsa yang mampu bersaing dikompetisi global. Perkembangan pesantren dari waktu ke waktu mengalami kemajuan yang cukup signifikan. Perkembangan itu ditandai dengan adaptasi dan inovasi tiada henti dari berbagai aspek menyesuaikan diri dengan tantangan dan kebutuhan zamannya.

Pergumulan pesantren dengan berbagai problematikanya dalam menghadapi perubahan dan kemajuan zaman telah membantu membangun jati dirinya sebagai lembaga pendidikan yang kokoh dan mengakar pada tradisi masyarakat di mana ia berada dan dilahirkan. Keberadaannya di tengah-tengah masyarakat senantiasa menjadi wadah perekat umat serta sebagai centre of agent, yaitu ; 1) agent of change (agen perubahan), 2) agent of knowladge (agen ilmu pengetahuan), dan 3) agent of culture (agen budaya) (Muttaqin, 2011).

Adapun populasi pondok pesantren terbesar berada di Provinsi Jawa Barat sebanyak 7.624 pondok (28\%), Jawa Timur sebanyak 6.003 pondok (22,05\%), Jawa Tengah sebanyak 4.276 (15,70\%), Banten sebanyak 3.500 pondok (12,85\%) dan sisanya sebesar 21,4\% atau setara dengan 5.827 pondok berada di provinsi lain. Kita akan melihat peran sertifikasi kompetensi syariah akankah berpengaruh pada perkembangan pariwisata syariah Indonesia guna menghadapi persaingan global.

\section{Tinjauan Pustaka}

\section{Pesantren}

Pondok esantren adalah artefak peradaban Indonesia yang dibangun sebagai institusi pendidikan keagamaan bercorak tradisional, unik dan indigenous (Zarkasyi, 2015). Sebagai artefak peradaban, pesantren tidak hanya identik dengan keislaman, tetapi juga mengandung makna keaslian Indonesia (Gamal, 2010). Keberadaan pesantren memiliki keterkaitan yang kuat dengan sejarah dan budaya yang berkembang pada awal berdirinya.

Pesantren menurut Alwi, (2016) adalah salah satu lembaga di antara lembagalembaga iqamatuddin lainnya yang memiliki dua fungsi utama, yaitu kegiatan tafaqquh fi-aldin (pengajaran, pemahaman, dan pendalaman ajaran agama Islam), serta fungsi indz̧bar (menyampaikan dan mendakwahkan ajaran kepada masyarakat). Sejarah pendidikan Indonesia mencatat, bahwa pesantren adalah bentuk lembaga pendidikan pribumi tertua di Indonesia. Ada dua pendapat mengenai awal berdirinya pesantren di Indonesia, pendapat pertama menyebutkan bahwa pesantren berakar pada tradisi Islam sendiri dan pendapat kedua mengatakan bahwa sistem pendidikan model pesantren adalah asli Indonesia

Latar belakang pesantren yang paling penting untuk diperhatikan adalah peranannya sebagai transformasi kultural yang menyeluruh dalam kehidupan masyarakat agamis. Pesantren bertindak sabagai jawaban terhadap panggilan keagamaan, menegakkan ajaran dan nilai-nilai agama melalui pendidikan keagamaan dan pengayoman serta dukungan kepada kelompok-kelompok yang bersedia menjalankan perintah agama dan mengatur hubungan mereka secara pelan-pelan. Secara rinci fungsi pesantren dapat 
dijelaskan sebagai berikut: sebagai lembaga pendidikan, sebagai lembaga sosial, lembaga penyiaran agama (lembaga dakwah), pusat pengembangan ekonomi kerakyatan, sebagai agent of development, sebagai center of excellence.

\section{Pariwisata Syariah}

Ekonomi global kembali meningkat pada 2016 sebagai faktor pendorong sektor pariwisata dari sisi permintaan. Indonesia juga mengalami peningkatan di dunia Pariwisata, dari 9,3 juta tahun 2014 menjadi 10,4 juta tahun 2015 (naik 2,9 \%), dan tahun 2016 menembus angka 12 juta kunjungan wisatawan mancanegara. Dibandingkan dengan negara lain di ASEAN, Indonesia berada di peringkat keempat, di bawah Thailand, Malaysia, Singapura. Berdasarkan kewarganegaraan, Singapura, Malaysia dan Tiongkok adalah 3 kontributor wisatawan mancanegara terbesar, sedangkan dari luar Asia terdapat, Australia, Inggris, dan Amerika Serikat (Crescentrating, 2017).

Konsep syariah dalam industri pariwisata adalah penerapan dari segala hal yang tidak bertentangan dengan nilai-nilai dan etika syariah berhubungan dengan konsep halal dan haram di dalam Islam (Soebagyo, 2018). Halal diartikan dibenarkan, sedangkan haram diartikan dilarang. Konsep halal dapat dipandang dari dua perspektif yaitu perspektif agama dan perspektif industri. Yang dimaksud dengan perspektif agama, yaitu sebagai hukum makanan apa saja yang boleh dikonsumsi oleh konsumen muslim sesuai keyakinannya. Hal ini membawa konsuekensi adanya perlindungan konsumen. Sedangkan dari perspektif industri, bagi produsen pangan, konsep halal ini dapat diartikan sebagai suatu peluang bisnis. Bagi industri pangan yang target konsumennya sebagian besar Muslim, diperlukan adanya jaminan kehalalan produk akan meningkatkan nilainya yang berupa intangible value. Produk pangan yang kemasannya tercantum label halal dianggap lebih menarik bagi konsumen Muslim.

The United Nation of World Tourism Organization menyebutkan bahwa konsumen wisata syariah bukan hanya umat Muslim tapi juga non Muslim yang ingin menikmati kearifan lokal. Kriteria umum pariwisata syariah ialah; pertama, memiliki orientasi kepada kemaslahatan umum. Kedua, memiliki orientasi pencerahan, penyegaran, dan ketenangan. Ketiga, menghindari kemusyrikan dan khurafat. Keempat, bebas dari maksiat. Kelima, menjaga keamanan dan kenyamanan. Keenam, menjaga kelestarian lingkungan. Ketujuh, menghormati nilai-nilai sosial budaya dan kearifan lokal.

\section{Metode Penelitian}

1. Jenis dan Sumber Data

Penulisan karya tulis ini menggunakan data sekunder yang meliputi buku-buku yang relevan dengan topik penulisan, karya tulis ilmiah, artikel, serta jurnal dari internet. Kami juga menggunakan data tidak langsung dari kutipan pernyataan beberapa orang yang berkompeten dan berkaitan dengan permasalahan yang dibahas dalam karya tulis ini. Sumber data berasal dari Kementerian Pariwisata dan Ekonomi Kreatif (Kemenparekraf) 
sekarang bernama Kementerian Pariwisata (Kemenpar), Badan Pusat Statistik (BPS), dan instansi lainnya.

2. Teknik Pengumpulan Data dan Informasi

Metode pengumpulan data dilakukan melalui studi kepustakaan yang mendalam dan pencarian data mengenai obyek permasalahan yang dibahas dalam karya tulis. Studi kepustakaan menggunakan referensi-referensi umum dan khusus. Untuk semakin mendukung dan memperkuat ketepatan dan kredibilitas dari penulisan informasi juga dilakukan pengumpulan data melalui internet.

3. Pendekatan Penulisan

Pendekatan yang digunakan dalam penulisan karya tulis ini adalah deskripsi kualitatif berdasarkan kajian kepustakaan. Dalam pemilihan pendekatan ini diharapkan dapat memberikan gambaran secara cermat mengenai keadaan dan gejala tertentu pada obyek yang menjadi permasalahan.

4. Metode Analisis dan Pengelolaan Data

Analisis data dilakukan dengan metode kualitatif untuk menganalisis faktor-faktor pentingnya sertifikasi kompetensi syariah untuk SDI Indonesia di bidang pariwisata syariah.

\section{Hasil dan Pembahasan}

1. Peluang dan Tantangan Pariwisata Syariah Indonesia

Adanya pasar bebas ASEAN meningkatkan wisatawan di ASEAN karena setiap negaranya banyak melakukan persiapan, perbaikan di setiap sektor yang dimiliki guna meningkatkan daya saing dengan negara anggota ASEAN lainnya. Keberadaan MEA pun memberikan peluang dan tantangan tersendiri bagi pariwisata syariah yang saat ini sedang dalam masa pertumbuhan hampir di seluruh dunia. Konsep wisata syariah ini telah banyak dipraktikkan di berbagai negara, seperti Arab Saudi, Malaysia, Jordania, Turki, dan negara lainnya dengan menunjukkan peningkatan pendapatan yang cukup signifikan bagi negaranegara tersebut. Sehingga konsep wisata syariah ini memilki potensi yang sangat besar untuk dikembangkan. Wakil Menteri Pariwisata dan Ekonomi Kreatif RI, Sapta Nirwandar menyebutkan potensi wisata syariah dunia bernilai US\$2,47 triliun atau setara Rp 28.837 triliun pada 2018 mendatang. Pasalnya, tiap tahun wisatawan muslim dunia terus meningkat secara signifikan. Peningkatan wisatawan muslim dunia sejalan semakin besarnya kebutuhan wisata muslim friendly'.

Potensi pariwisata syariah di tanah air dinilai besar. Apalagi pariwisata syariah sudah menjadi tren di dunia. Peluang pariwisata syariah Indonesia, antara lain: Indonesia memiliki jumlah penduduk terbanyak di ASEAN. 39\% dari total penduduk ASEAN merupakan penduduk Indonesia. Hal ini menjadikan Indonesia sebagai pasar yang menjanjikan bagi pengembangan sektor pariwisata syariah. Bagi Indonesia, potensi pariwisata syariah bukan hanya untuk pasar luar negeri saja. Tapi juga besarnya potensi wisatawan nusantara dan terus mengalami kenaikan. Menurut data Kementerian Pariwisata dan Ekonomi Kreatif, pada 2011 tercatat sekitar 239 juta pergerakan wisatawan 
nusantara dengan pengeluaran sekitar Rp 138 triliun. Sedangkan, pada 2012 tercatat sekitar 245 juta pergerakan wisatawan. Jika 88,1\% pelaku perjalanan adalah penduduk muslim maka akan didapat sekitar 215 juta pergerakan dengan pengeluaran diperkirakan sebesar US\$129,37 miliar atau sekitar Rp 142,3 triliun.

Indonesia memiliki penduduk mayoritas muslim. Dari 240 juta jiwa penduduk Indonesia, 88\%-nya merupakan penduduk muslim yang menjadi target potensial untuk pariwisata syariah. Mayoritas muslim-nya memiliki kesempatan sangat besar untuk mengembangkan pariwisata syariah, bahkan berpotensi menjadikan Indonesia menjadi pusat pariwisata syariah dunia.

Indonesia memiliki banyak daerah potensial yang dapat dikembangkan segi wisatanya, bahkan secara syariah mulai terbentuk pangsa pasar yang terus semakin meluas yang mencari gaya hidup sehat, ramah lingkungan, dan menilai spiritual keseimbangan kehidupan.Produk-produk halal tidak hanya dikonsumsi oleh turis muslim saja tetapi juga oleh para turis non-muslim.Hal ini karena semakin tingginya kesadaran setiap orang akan pentingnya manfaat dari konsep halal, baik dalam makanan, wisata, jasa keuangan, dan lain-lain. Berdasarkan LPPOM-MUI tahun 2011 tercatat bahwa pada tahun 2009, indeks kesadaran produk halal berkisar 70\% meningkat menjadi $92 \%$ pada 2010 , serta jumlah produk bersertifikat halal naik 100\% dalam kurun waktu 2009-2010. Hal tersebut menunjukkan kesadaran dari masyarakat akan pentingnya manfaat dari produk halal tersebut.

Kemenparekraf sudah melakukan sertifikasi tempat-tempat tujuan wisata yang potensial dikunjungi para wisatawan muslim. Sertifikasi Usaha Hotel Syariah adalah bukti tertulis yang diberikan oleh DSN-MUI pada usaha hotel yang telah memenuhi penilaian kesesuaian kriteria Usaha Hotel Syariah. Selain peluang, pertumbuhan dan perkembangan pariwisata syariah Indonesia juga harus melewati beberapa tantangan, antara lain: Pelaku usaha pariwisata syariah belum berani mengambil risiko kehilangan pasar selain muslim; wawasan dan tingkat kesadaran pelaku usaha terhadap potensi besar pariwisata syariah di Indonesia; sosialisasi dan promosi wisata syariah masih kurang gencar, dibutuhkan dukungan khusus dari pemerintah.

\section{Peran Pondok Pesantren dalam Program Sertifikasi Kompetensi Syariah sebagai Upaya Pengembangan Pariwisata Syariah di Indonesia \\ Sama seperti pentingnya sertifikasi kompetensi bagi peningkatan kualitas pariwisata} di Indonesia, maka diperlukan pula sertifikasi kompetensi syariah untuk mengembangkan pariwisata syariah yang sedang dalam masa pertumbuhan. Pariwisata syariah bukan hanya tren sementara tapi akan terus eksis dan berkembang dengan subur, bahkan diprediksi akan menjadi primadona pariwisata dunia sekaligus lifestyle bagi masyarakat, tak terkecuali di Indonesia berdasarkan peluang dan kebutuhan masyarakat yang telah dipaparkan pada subbab sebelumnya.

Sertifikasi kompetensi syariah menjadi salah satu solusi atau upaya mencetak dan mempersiapkan SDI-SDI yang berkompeten untuk menggerakkan pariwisata syariah di 
Indonesia. Tahap pertumbuhan dilanjutkan dengan tahap perkembangan sampai pariwisata syariah memiliki daya saing yang kuat dengan industri pariwisata secara umum, termasuk pariwisata syariah di negara-negara lain yang telah lebih dulu memajukan pariwisata syariah.

SDI bidang pariwisata itu sendiri dapat dibagi menjadi 3 kategori. Setiap kategorinya memiliki alasan masing-masing untuk perlu melakukan sertifikasi kompetensi syariah, seperti pada bagan berikut:

\section{Gambar 1}

\section{Kompetensi SDI Pariwisata}

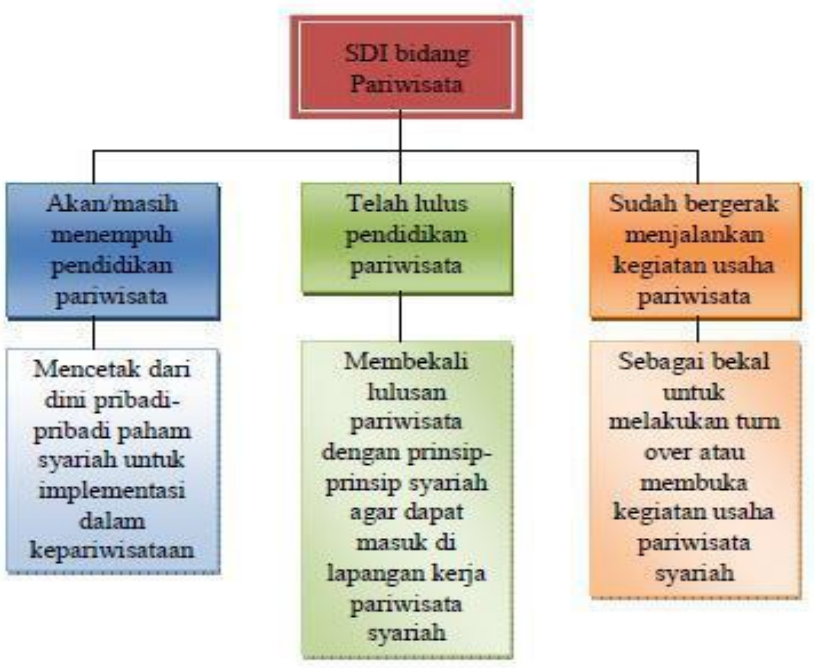

Selain alasan pentingnya sertifikasi kompetensi syariah, sertifikasi kompetensi syariah bidang pariwisata syariah memiliki 4 fungsi, antara lain: memenuhi kebutuhan bisnis (legal liability scheme), mengantisipasi globalisasi sehingga SDI pariwisata syariah memiliki daya saing yang tinggi dan perlu pengakuan formal bagi lulusan Perguruan Tinggi untuk menjadi tenaga profesional dan pelatihan bagi lulusan sekolah SMA atau SMP agar memilki kemampuan dalam menghadapi arus globalisasi.

Bukti kemandirian profesional di bidang pariwisata dengan memiliki nilai-nilai dan etika dalam Islam adalah 3 pilar utama sertifikasi kompetensi di bidang pariwisata syariah:

\section{Gambar 1}

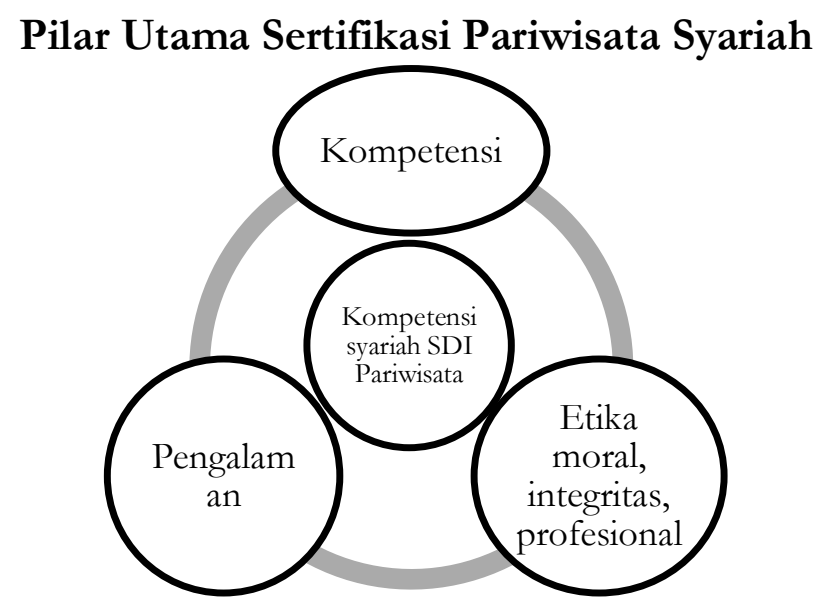


Pesantren merupakan sebuah lembaga yang melekat dan tidak dapat di pisahkan dalam kontruksi social di Indonesia. SDI pesantren merupakan sebuah modal untuk menghadapi era modern dan semakin berkembang apalagi dengan adanya MEA serta yang terbaru ini ialah era industry Halal, oleh karna itu pesantren dapat dikatakan wujud atau motor dalam perkembangan serta kemajuan perekonomian Indonesia khususnya dalam bidang ekonomi syariah hal itu dengan bagaimana banyaknya pariwisata syariah yang di harapkan semakin berkembang.

Di era MEA serta industry halal pesantren tidak hanya di harapakan menjadi tempat edukasi keilmuan namun pesantren di harapkan juga bisa menjadi factor utama dalam perkembangan pariwisata syariah hal itu mungkin bisa dilakukan dengan adanya sertifikasi serta pembekalan kompentensi dalam bidang perekonomian sepeti yang ada dalam bagan ini akan memberikan sebuah gambaran mengenai pesantren dan SDI pariwisata syariah yang seharusnya dilakukan oleh pesantren.

\section{Gambar 3}

\section{Prosedur Pengajuan dan Penerimaan Kompetensi Syariah}

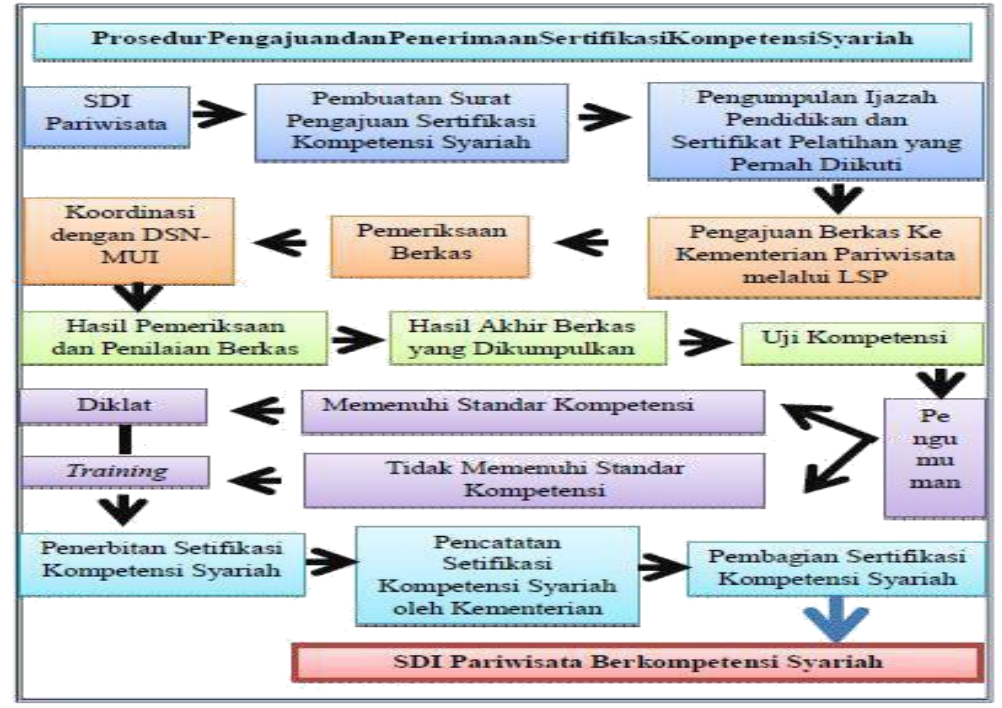

\section{Etika, moral, dan integritas profesional.}

Sertifikasi kompetensi syariah SDI pariwisata ini konsepnya hampir mirip dengan program sertifikasi yang lain, hanya saja dalam sertifikasi ini terdapat kriteria-kriteria khusus mengenai kompetensi dasar hukum Islam. Seperti memahami konsep halalan thoyyiban, memilki sifat amanah, jujur, bertanggung jawab, pencatatan akuntansi sesuai prinsip Islam, dan lain sebagainya.

Bercermin pada skema sertifikasi kompetensi di bidang pariwisata sesuai amanat Peraturan Pemerintah Nomor 52 Tahun 2012 tentang Sertifikasi Kompetensi dan Sertifikasi Usaha Bidang Pariwisata, maka sertifikasi kompetensi syariah di bidang pariwisata syariah mencakup pengembangan standar kompetensi syariah, penyusunan SKKNI bidang pariwisata syariah yang telah dikoordinasikan antara instansi pemerintah 
bidang pariwisata, asosiasi usaha pariwisata, asosiasi profesi pariwisata, akademisi, dan DSN-MUI.

Pengembangan skema sertifikasi kompetensi syariah di bidang pariwisata syariah mengacu pada KKNI (Kerangka Kualifikasi Nasional Indonesia), kualifikasi okupasi nasional, kelompok, unit kompetensi dan profisiensi yang berdasarkan prinsip-prinsip syariah. Penerapan sertifikasi kompetensi syariah di bidang pariwisata syariah pemberlakuannya bersifat wajib dan Pelaksana sertifikasi kompetensi syariah dilakukan oleh LSP (Lembaga Sertifikasi Profesi) bidang pariwisata yang telah bekerja sama dengan DSN-MUI.

Pelaksanaan sertifikasi tersebut berdasarkan 3 kategori utama, yaitu saat proses pembelajaran kompetensi yang dilakukan pada saat SDI masih berada pada lembaga pendidikan pariwisata. Kedua, hasil pembelajaran yakni proses pengakuan capaian pembelajaran/kompetensi syariah yang diperoleh melalui pendidikan nonformal, informal, dan pelatihan. Ketiga adalah hasil pengalaman kerja, yaitu akumulasi melakukan pekerjaan secara intensif pada jangka waktu tertentu di bidang pariwisata syariah yang menghasilkan peningkatan kompetensi syariah. Selanjutnya, harmonisasi dan pengakuan sertifikasi kompetensi syariah di bidang pariwisata syariah. Ditujukan untuk membangun pengakuan terhadap kompetensi syariah pemegang sertifikat kompetensi syariah di bidang pariwisata syariah.

SDI pariwisata yang tersedia di Indonesia dapat mengajukan Surat Permohonan untuk mendapatkan Sertifikasi Kompetensi Syariah dengan melengkapi berkas-berkas berupa pengisian formulir pengajuan sertifikasi, ijazah pendidikan, sertifikat pelatihan yang berkaitan dengan pariwisata dan syariah yang pernah diikuti, dan prestasi yang pernah diraih di kedua bidang tersebut (jika ada). Selanjutnya, bekas-berkas yang telah dilengkapi, diajukan kepada Kementerian Pariwisata RI melalui LSP untuk dilakukan pemeriksaan berkas. Berkas-berkas yang telah masuk ke Kementerian Pariwisata kemudian dikirim ke MUI untuk melakukan koordinasi terkait penilaian berkas berdasarkan standar kompetensi yang telah ditetapkan.

Kemudian setelah dilakukan penilaian dan pemeriksaan kembali berkas oleh DSN-MUI, hasil akhir pun diperoleh sebagai dasar penentuan kompetensi yang dimiliki oleh SDI pengaju Sertifikasi Kompetensi Syariah. Apabila hasil penilaian memenuhi standar kompetensi yang berlaku, maka SDI pariwisata tersebut akan diikutkan Diklat selama 3bulan. Namun, apabila hasil penilaian tidak memenuhi standar kompetensi, pengaju diharuskan untuk mengikuti training selama 6 bulan Diklat dan training yang diberikan bertujuan untuk memberikan keahlian kepada SDI pariwisata. Keahliankeahlian yang diberikan meliputi aspek-aspek yang sesuai dengan standar kompetensi. Sehingga ketika training selesai, Sertifikasi Kompetensi Syariah diterbitkan serta dicatat oleh Kementerian Pariwisata, para pengaju sertifikasi ini telah memiliki kemampuan dasar yang sesuai dengan standarisasi. Sehingga, SDI pariwisata berkompetensi syariah siap untuk menjalankan dan mengembangkan pariwisata syariah di Indonesia. 
Setelah SDI Pariwisata memiliki kompetensi syariah berdasarkan standarisasi yang telah ditetapkan melalui training/diklat, maka terdapat hak dan kewajiban dalam menjalankan profesinya, yaitu:

a. Hak

1. Mendapatkan bukti tertulis berupa Sertifikat Kompetensi Syariah dari Kementerian Pariwisata yang bekerja sama dengan MUI.

2. Mendapatkan jaminan hukum atas profesi sebagai SDI Pariwisata Syariah.

3. Mendapatkan buku panduan mengenai standarisasi, etika, hukum, dan sejarah.

4. Mendapatkan pelayanan konsultasi atas permasalahan yang dihadapi secara teknis dalam pelaksanaan profesi sebagai SDI Pariwisata Syariah.

5. Mendapatkan kemudahan untuk bekerja di dalam negeri dan negara anggota ASEAN, khususnya pada era perdagangan bebas MEA.

b. Kewajiban

1. Menjalankan profesi sebagai SDI pariwisata yang berbasis kompetensi syariah.

2. Menerapkan prinsip-prinsip syariah dalam pariwisata.

3. Melayani masyarakat domestik dan luar negeri dengan etika pariwisata syariah.

4. Meluaskan makna pariwisata syariah sebagai wisata yang berbasis prinsip Islami dengan destinasi dan obyek wisata yang luas.

5. Menjaga nama baik Kementerian Pariwisata RI di dalam dan luar negeri.

6. Mengembangkan Pariwisata Syariah Indonesia sesuai dengan kemampuan masing-masing.

7. Meningkatkan etos kerja demi pertumbuhan pariwisata syariah sehingga mendorong berkembangnya sektor-sektor ekonomi lain di Indonesia.

Sebagai tenaga kerja di bidang pariwisata, sertifikasi berdasarkan standar kompetensi yang telah ditetapkan merupakan hal penting untuk meningkatkan kualitas SDI serta mendukung daya saing pariwisata Indonesia di internasional. Berlaku pula untuk pengembangan pariwisata syariah. Dengan adanya sertifikasi kompetensi syariah tersebut akan menjadi pendorong untuk para SDI pariwisata syariah dalam mempersiapkan diri dalam menyambut era revolusi industri Halal.

\section{Kesimpulan}

Pariwisata merupakan sektor dengan kontribusi terbesar dalam perdagangan internasional dan menjadi pendorong utama dalam perkembangan sosial-ekonomi dunia. Ditambah dengan kehadiran konsep pariwisata syariah yang sedang menjadi tren dan diprediksi akan bertahan dalam jangka waktu yang lama. Bagi negara Indonesia dengan penduduk terbanyak dan mayoritas muslim, tren pariwisata syariah memberikan keuntungan terutama untuk penguatan sektor pariwisata dalam menghadapi MEA 2015.

Pariwisata syariah telah berkembang baik di negara-negara tetangga, seperti Malaysia. Berbagai peluang dan tantangan yang dimiliki Indonesia, menempatkannya pada kesempatan besar untuk menumbuhkembangkan pariwisata berbasiskan syariah ini. Salah satu faktor penting yang mempengaruhi kualitas pariwisata syariah adalah kompetensi dari 
SDI-SDI pariwisata penggeraknya. Sejauh ini, sertifikasi kompetensi belum diterapkan dengan dasar prinsip syariah yang secara khusus untuk membangun kualitas pariwisata syariah.

Sertifikasi Kompetensi Syariah merupakan bukti tertulis atas peningkatan kemampuan yang dimiliki oleh SDI pariwisata Indonesia berdasarkan prinsip Islam demi penguatan daya saing Indonesia dalam menghadapi persaingan global. Sertifikasi kompetensi syariah diperlukan untuk mengembangkan pariwisata syariah yang sedang dalam masa pertumbuhan. Pengadaan sertifikasi kompetensi syariah akan menghasilkan SDI-SDI berkompeten yang akan mampu menggerakkan pariwisata syariah dengan kualitas dan daya saing yang tinggi.

\section{DAFTAR PUSTAKA}

Alwi, B. M. (2016). Pondok Pesantren: Ciri Khas, Perkembangan, Dan Sistem Pendidikannya. Lentera Pendidikan : Jurnal Ilmu Tarbiyah Dan Keguruan. https://doi.org/10.24252/lp.2013v16n2a8

ASEAN.“Tourism Statistics”http://www.asean.org/news/item/tourism-statistics, 2012

Crescentrating. (2017). Global Muslim Travel Index (GMTI) 2017. Crescentrating.Com. https://doi.org/10.1016/j.jweia.2015.05.010

G.T. Suroso. (2015). Masyarakat Ekonomi Asean (MEA) dan Perekonomian Indonesia. Badan Pendidikan Dan Pelatihan Keuangan Kementerian Keuangan.

Gamal Abdul Nasir Zakaria. (2010). Pondok Pesantren : Changes and Its Future. Journal of Islamaic and Arabic Education.

Invesments, I. (2016). Industri Pariwisata Indonesia.

Kementerian Pariwisata dan Ekonomi Kreatif."Indonesia Bidik Wisatawan Muslim

Melalui Pengembangan Wisata Syariah”

http:/ parekraf.go.id/asp/detil.asp?c=16\&id=2447 2013.

Kementerian Perindustrian. "Indonesia Terlambat Hadapi MEA2015"

http:/ / kemenperin.go.id/artikel/ 8055/Indonesia-Terlambat-Hadapi-MEA-

2015,2015.UNW'T.“UNW'TOTourismHighlights”dari

http://mkt.unwto.org/publication/unwto-tourism-highlights-2014-editio

Muhajirin, M. (2018). Pariwisata Dalam Tinjauan Ekonomi Syariah. Al-Mashlahah: Jurnal Hukum Islam Dan Pranata Sosial. https:/ / doi.org/10.30868/am.v6i01.241

Muttaqin, R. (2011). Kemandirian dan pemberdayaan ekonomi berbasis pesantren (. JESI Jurnal Ekonomi Syariah Indonesia.

Soebagyo, S. (2018). Strategi Pengembangan Pariwisata Di Indonesia. Liquidity. https://doi.org/10.32546/lq.v1i2.145

Wangke, H. (2015). Peluang Indonesia Dalam Masyarakat Ekonomi Asean 2015. Info Singkeat Hubungan Internasional.

Zarkasyi, H. F. (2015). Modern Pondok Pesantren: Maintaining Tradition in Modern System. Tsaqafah. https://doi.org/10.21111/tsaqafah.v11i2.267 